\title{
Hydatid Cyst at Unusual Sites: An Original Study with Review of Literature.
}

\author{
Dr. Aarti. B. Bhattacharya ${ }^{1}$, Dr. S P Rai ${ }^{2}$, Dr. R K Agrawal ${ }^{3}$ \\ 1. Professor Dept. of Pathology, Hind Institute of Medical Sciences Safedabad. Barabanki UP India \\ 2. Assistant Professor Dept.of Orthopaedics Hind Institute of Medical Sciences Safedabad.Barabanki UP India. \\ 3. Assistant Professor Dept.of Surgery Hind Institute of Medical Sciences Safedabad. Barabanki UP India
}

\begin{abstract}
Echinococcosis a zoonotic infection caused by echinococcusgranulosus is still a large extended public health problem in endemic regions. Primary echinococcosis may develop in almost any organ or tissue. The liver and the lungs are the most frequently involved organs. Primary hydatidosis of soft tissue involving foot, coccygeal region and breast is extremely rare even in endemic areas. After diagnosing 6 cases of primary hydatid cyst over a period of three years we present three selected rare cases of isolated primary hydatid cyst one each in left breast, left foot (soft tissue), and coccygeal region (soft tissue) along with a review of literature and discussion on the pertinent clinical features, management and prognostic aspects of the disease.
\end{abstract}

Key-words: Echinococcusgranulosus, Hydatid cyst, Hydatid cyst in breast, Hydatid cyst in other soft tissues.

\section{Introduction}

Echinococcosis has a worldwide distribution with high prevalence in endemic areas (viz. Australia, New Zealand, Tasmania, Turkey, Greece, South America, Russia, China, India and Pakistan).Poor socioeconomic conditions, poor hygiene and lack of clean potable water supply results in endemcity. [1] Also majorityof the patientsare from rural background. These patients acquire the infection in childhood. [2]Humans are accidental intermediate hosts. The adult worm lives in the dog(Definite host).Humans host the larval stage. The lifecycle of the larva in a human ends with bacterial infection resulting in shrinkage of the cystand eventual calcification.[2, 3]The parasite may affect any organ or tissue (liver, lung, kidney, spleen, mediastinum, peritoneum, heart, brain, bone, muscle, pancreas, breast, ovary etc.)[3]. Symptoms differ according to the site of hydatid cyst, but basically it presents as a slowly growing benign cystic lesion. Hydatid cysts of soft tissues are very unlikely and of low prevalence[3] hence a very high index of suspicion is required for its diagnosis. A complicated soft tissue hydatid cyst may mimic a soft tissue tumour, chronic abscess or a chronic haematoma. Preoperative possibility of hydatid cyst must be borne in mind.

\section{Material and Method}

During a period of three years (Aug 2009-Aug 2012) we reported 6 cases of primary hydatidosis of different sites. We reviewed carefully three rare cases of primary hydatidosis of left breast, left foot and coccygeal region. The patients were carefully followed up.

2.1 Case History: We herein present description of three cases in table (1)

TABLE: (1)

\begin{tabular}{|c|c|c|c|}
\hline & Case -1 & Case -2 & Case - 3 \\
\hline Age/Sex/Weight & $45 \mathrm{yr} / \mathrm{F} / 40 \mathrm{~kg}$ & $30 \mathrm{yr} / \mathrm{M} / 54 \mathrm{~kg}$ & $45 \mathrm{yr} / \mathrm{M} / 56 \mathrm{~kg}$ \\
\hline History & $\begin{array}{l}\text { Slow growing, painless lump in } \\
\text { left breast (upper outer } \\
\text { quadrant) }\end{array}$ & $\begin{array}{l}\text { Slow growing painless mass } \\
\text { on left foot (Dorsum, proximal) }\end{array}$ & $\begin{array}{l}\text { Slow growing cystic mass in } \\
\text { coccygeal region. }\end{array}$ \\
\hline Duration: & 8months & $2 \mathrm{yrs}$ & 6months \\
\hline FNAC: & Acellular smear & Lymphoepithelial cyst & Lymphoepithelial cyst \\
\hline USG: & Cyst with multiple small cysts. & Multiloculated cyst & Multiloculated cyst \\
\hline Surgical treatment & Complete careful excision. & Complete careful excision. & Complete carefull excision. \\
\hline Gross examination: & $\begin{array}{l}\text { Multiplecysts grey white } \\
\text { glistening. }\end{array}$ & $\begin{array}{l}\text { Multiloculated cyst } \\
\text { Grey white glistening. }\end{array}$ & $\begin{array}{l}\text { Multiloculated cyst } \\
\text { Grey white glistening. }\end{array}$ \\
\hline Histopathology & $\begin{array}{l}\text { Endocyst, exocyst and pericyst } \\
\text { revealed }\end{array}$ & $\begin{array}{l}\text { Endocyst, exocyst and pericyst } \\
\text { revealed }\end{array}$ & $\begin{array}{l}\text { Endocyst, exocyst and pericyst } \\
\text { revealed }\end{array}$ \\
\hline
\end{tabular}


Hydatid Cyst At Unusual Sites: An Original Study With Review Of Literature.

\begin{tabular}{|l|l|l|l|}
\hline & hydatid cyst left breast & hydatid cyst left foot. & $\begin{array}{l}\text { microphotographs-exocyst and } \\
\text { pericyst }(\text { H\&Ex400) }\end{array}$ \\
\hline Medical treatment & $\begin{array}{l}\text { Tab.Albendazole } 10 \mathrm{mg} / \mathrm{kg} / \mathrm{day} \\
\text { for six weeks. }\end{array}$ & $\begin{array}{l}\text { Tab.Albendazole } 10 \mathrm{mg} / \mathrm{kg} / \mathrm{day} \\
\text { for six weeks. }\end{array}$ & $\begin{array}{l}\text { Tab.Albendazole } 10 \mathrm{mg} / \mathrm{kg} / \mathrm{day} \\
\text { for six weeks. }\end{array}$ \\
\hline Follow - up Study & No recurrent disease in $2 \mathrm{yrs}$ & No recurrent disease in $2 \mathrm{yrs}$ & No recurrent disease in $2 \mathrm{yrs}$ \\
\hline
\end{tabular}

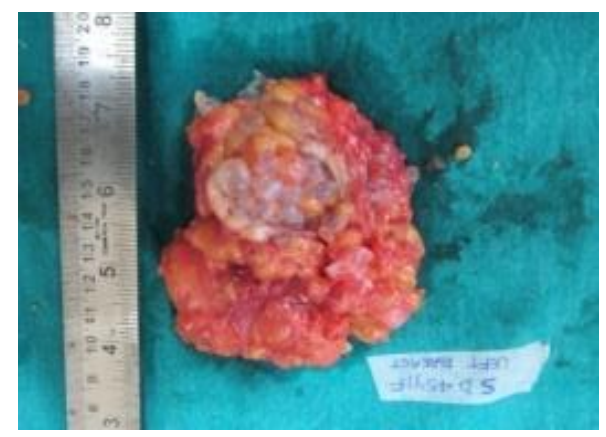

Fig 1 Sp. of Hydatid cyst in Left breast.

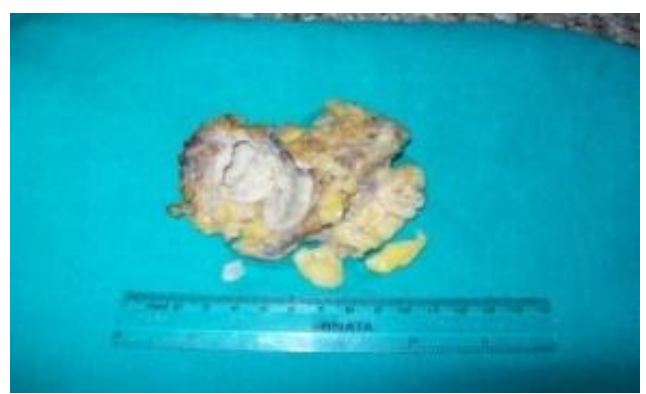

Fig 2 Sp. of Hydatid cyst in left foot.

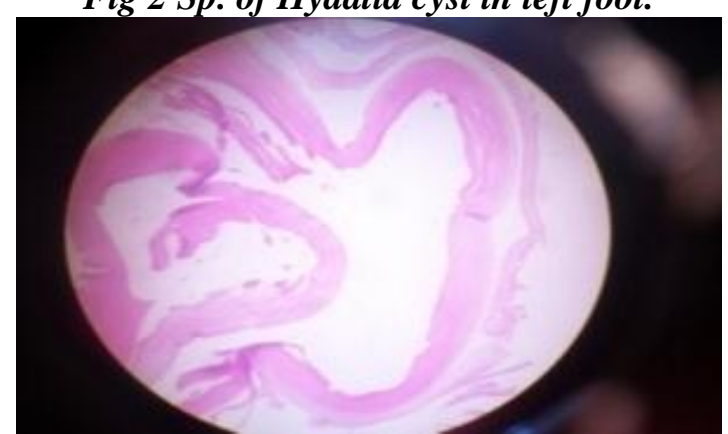

Fig 3.Exocyst (Chitinous wall) of hydatid cyst (H\&Ex400)

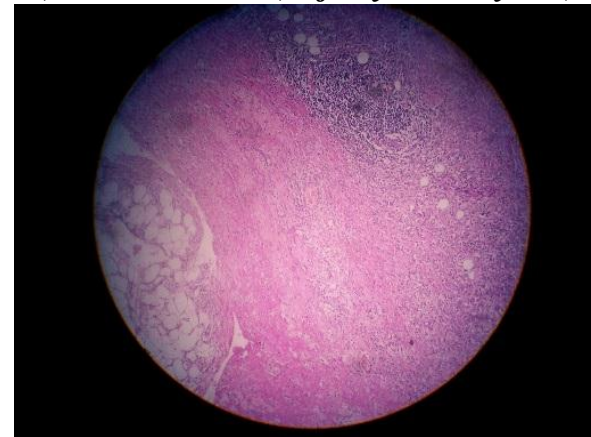

Fig 4.Pericyst (Host reaction), Left Breast $(H \& E X$ X00)

III.Discussion:

The patients in the study were from rural background with history of contact with dogs, and cattle.[1,2] In all the three patients, isolated primary hydatid cyst was diagnosed at unusual sites. Hydatid cyst in breast is very rare with an incidence of $0.27 \%$ [4]. Hydatid cyst of the soft tissue is also very rare.[3] Patients were radiologically investigated (CXR and USG abdomen were performed) to rule out hydatid cysts in the common sites. [1,2,]USG in the first case revealed multiple daughter cysts in a large cyst, which 
was diagnostic of hydatid cyst [6]. Remaining two cases showed multiloculated cysts [6]. Diagnosis of hydatid cyst was doubtful."Anti-ecchinococcal antibody[IgG] was not done as all the three patients could not afford it. On FNAC, clear watery fluid was aspirated, keeping hydatid cyst in mind the patients were closely observed for any untoward reaction(Anaphylactic). It was uneventful. Cytologically no protoscolices or fragments of membrane were seen. [7].Hydatid cyst was suspected so the surgeons were alerted, the cystic masses were excised in-toto carefully [10].Surgery is associated with a recurrence rate of $2 \%$. A recent study states that overall fatality rate due to anaphylaxis from puncture of hydatid cysts is $0.03 \%$ for operative procedures. Puncture-aspiration of cyst contents-infusion of scolicidal agents and reaspiration (PAIR) has been used as a percutaneous treatment of hydatid cysts in liver, peritoneum, spleen, kidneys, and muscle. Gross examination of the surgical specimens revealed multiple greywhite glistening cysts in the breast lump, whereas the foot and coccygeal masses showed multiloculated cyst with scanty serous fluid. Microscopy of the unstained and stained centrifuged cyst fluid did not reveal hooklets and scolices. Histopathology confirmed the diagnosis of hydatid cyst showing very prominent chitinous wall and the host tissue reaction to the presence of the parasite. The endocyst could also be made out distinctly. Tab. Albendazole was administered orally with meal, dose being tailored according to patient's weight[8].After discharge on albendazole treatment the patients' Hb, TLC, DLC, SGOT, SGPT, Alkaline Phosphatase were routinely estimated. Routine USG was done. The patient was educated about hydatid cyst infection, about proper disposal of sheep viscera in abattoirs and to maintain distance from dogs and other animals.[1]All patients in the study were explained about the good prognosis in their respective cases. In general prognosis is good and depends on the cyst location. [3]

\section{IV.Conclusion}

No site is immune to hydatid cyst hence in endemic and also non-endemic areas hydatid cyst should be included in the differential diagnosis of a slowly growing benign cystic mass. A multiloculated cyst with sand grain appearance and multiple small cysts in a large cyst are highly suggestive of hydatid cyst. In cases where Anti-ecchinococcal antibody [IgG] test cannot be done radiological imaging is very helpful in diagnosing hydatidcyst. In fact rural background, long history of a benign cystic mass should raise the suspicion of hydatid cyst. Injudicious approach in the management of these cases may result in severe anaphylactic reaction and systemic dissemination. The surgical procedure should ideally be customized to each patient depending on the size, location and complication of each cyst. Intraoperative use of hypertonic saline or $0.5 \%$ silver nitrate injected into the cyst kills the daughter cysts. A survival rate of $95 \%$ has been reported in the patients undergoing surgical intervention. The diagnosis of soft tissue hydatid cyst requires a high index of suspicion. FNAC is uneventful but percutaneous needle biopsy is not recommended because of the possibility of introducing viable scolices into the needle tract. Our basic aim is to alert the reader to this rare manifestation so that an open biopsy will be avoided.

\section{References}

[1]. Lewise at al. A review of ecchinococcal disease. Ann Surg 1995; 18 (4): 390-396.

[2]. Kacheriwale SM, Mehta K.D, Pillai B, Jain Y - Rare presentation of primary hydatid cyst. Indian Jr of surgery 2004; 66 (1) : 4749.

[3]. Abi F, et Fares F, Khaiz D, Bouzidi A. Unusual localizations of hydatid cysts A propos of 40 cases. J chir (Paris) 1989; 126: 30712.

[4]. Taoril KB, Mahajan SM; Hirawe SR, Mundhada RG - Hydatid disease of breast. Indian J Radiol Imaging 2004; 14: 1: 57-60.

[5]. Engin G, Acunas B, Rozanes I, Acunas G. Hydatid disease with unusual Localization. Eur Radiol 2000, 10: 1904-12.

[6]. WHO informal working group. International classification of ultrasound images in cystic echinococcosis for application in clinical and field epidemiological settings. Acta Trop 2003, 85: 253- 61.

[7]. Kapila K, Verma K Aspiration cytology diagnosis of ecchinococcosis Diagn Cytopathol 1990; 6: 301-3.

[8]. Horton RJ. Albendazole in treatment of human cystic echinococcosis: twelve years of experience .Acta Trop 1997; 64: 79- 93.

[9]. Mohammed AE, Yasawy MI, AL karawi MA. Combined albendazole and praziquantal versus albendazole alone in the treatment of hydatid disease.Hepatogastroenterology 1998; 45:1690 -4

[10]. Safioleas M, Misiakos EP, Kakisis J, et al. Surgical treatment of human ecchinococcosis 2000; 85: 358-65. 